\title{
MULTILINGUALISM
}

\section{IN ANCIENT CONTEXTS}

\section{Perspectives from Ancient Near Eastern and Early Christian} Contexts

EDITORS

Louis C. Jonker Angelika Berlejung Izak Cornelius 


\title{
ARAMAIC OR NO ARAMAIC?
}

\section{Multilingualism and the Strategy of}

Language Choice in the Written Sources from the Ancient Near East

\author{
Angelika Berlejung \\ Leipzig / Stellenbosch/Bar-llan
}




\section{$2.1 \quad$ INTRODUCTION}

The term "multilingualism" (here and henceforth including "bilingualism") has individual and social, as well as political and institutional aspects. Contrary to popular ideas, these rarely run parallel. Multilingualism has different dimensions and can be defined differently. ${ }^{1}$ In this contribution multilingualism is mainly regarded as a social phenomenon and as a factor of individual linguistic behaviour. In the research on ancient sources and societies, where we only deal with ancient scribes, and not with speakers, aspects of individual and social multilingualism overlap. "Individual multilingualism" usually identifies individuals who know how to communicate in more than one language or a language and a dialect. "Social multilingualism" is the case when the use of two (or more) languages or a language and a dialect are determined by social spheres within a certain society or a certain region.

The different languages/dialects in a society have different functions/domains and different prestige levels. Closely related are the terms "élite" and "folk" multilingualism, which are closely linked to the status of the languages. ${ }^{2}$ Élites are usually speakers of high-status languages, while folks/lower classes are speakers of minority languages and dialects with lower prestige. Switchings/shifts between/to "high and low status languages" are usually context-sensitive, intentional, and meaningful. In addition, P. Bourdieu ${ }^{3}$ pointed out that linguistic practices represent power relations. According to him, the choice of the language can be related to the access to and the acquisition of capitals (according to his definitions of capitals). Thus, the choice of a language or script, its maintenance or shift mirror power relations. This is an aspect that plays a central role in the language choice and rules of text production in the multilingual societies of the Ancient Near East. The available written sources were mainly written or commissioned by members of the élite or the King.

Multilingualism may be observed in ancient Mediterranean societies since the 3rd millennium BCE. It was not the exception, but the rule - especially in urban centres and along the trade routes. The more extensively an empire developed in the past (in the 1st millennium BCE the Assyrians, Babylonians, Persians, Greeks, Romans), the more diverse it became in terms of languages and scripts. Simultaneously, communication within such a linguistically diverse empire was simply not possible Handbook of Pragmatics, eds., Anne Barron, Yueguo Gu \& Gerard Steen (London: Routledge, 2017), 139-150.

3 Pierre Bourdieu, Language and Symbolic Power (Cambridge, MA: Harvard University Press, 1991). 
without the development of a lingua franca and a scriptura franca which all (or, at least those in ideologically and economically relevant positions) could master.

In this discussion, I will focus on the Ancient Near East in the 1st millennium BCE, thus the following introductory remarks may be sufficient to sketch the linguistic situation shortly: It is widely accepted that the Aramaic language was utilised as the lingua franca in the ancient Near East during the 1st millennium BCE, and only lost the pole position in the 7 th century CE, with the rise of Arabic.

At the beginning, the Aramaic language was written in Phoenician script. Even if the typical Aramaic script is only fully recognisable around ca. $750 \mathrm{BCE},{ }^{4}$ and even if some regional differences in the chronological development of typical features of the Aramaic script (and of its descendants) must be taken into account: ${ }^{5}$ from the end of the 9 th/mid of the 8th century BCE onward already, the existence of an independent Aramaic script can be assumed. This is the same period in which the success of the Aramaic language (in the 9th/8th century in its central Syrian form) and its alphabet script can be observed. This success seems to be indebted to the political expansion and prestige of the central Syrian Kingdom of Damascus and to the rise, organisation and finally the cross-mass deportations of the Neo-Assyrian Empire. ${ }^{6}$

According to Holger Gzella, A Cultural History of Aramaic. From the Beginnings to the Advent of Islam, Handbook of Oriental Studies. Section 1 The Near and Middle East, Volume: 111 (Leiden: Brill, 2015), 60. The oldest inscription from the kingdom of Sam'al (KAl 24) during the time of King Kulamuwa (ca. 840-810 BCE) was (still) written in the Phoenician language and script (with Luwian influences). From the same reign is a dedicatory inscription that was still using the Phoenician script but Aramaic language (KAI 25). Then in the 9th century BCE the oldest Aramaic inscriptions emerged in northern Mesopotamia (early 9th century BCE Tell Halaf: KAI 231; Tell Fekheriyeh: KAI 309), Syria (Melqart stele: KAI 201), and northern Palestine/Galilee (second half of the 9th century BCE Tel Dan: KAI 310).

5 Epigraphical remains in Palestine are (at least if they predate the 8th century/Iron IIB) difficult to classify as Philistian, Phoenician or Aramaic (= PPA) because these PPA scripts are identical - only the Hebrew script developed some typical traits already in the Iron IIA1 = 880-840/30 BCE, visible in Tel Safi and Tel Rehov. Both sites attest in the Iron IIA1 Hebrew and non-Hebrew-PPA scripts side by side implying a certain local multilinguality; see Benjamin Sass \& Israel Finkelstein, "The West Semitic Alphabetic Inscriptions, Late Bronze II to Iron IIA: Archaeological Context, Distribution and Chronology", HeBAl 2 (2013): 149-220. The Aramaic script perhaps stimulated the development of the local Ammonite script (evolved in the Iron Age IIB); according to Sass \& Finkelstein, the Ammonite script has an "Aramaic, or rather undifferentiated non-Hebrew, precursor" (175). Different is the Moabite script that evolved away from the Hebrew script (as well in the Iron Age IIB).

The Aramaic language (or western and eastern dialects) and its alphabet script started to be used for international correspondence from the 9th/8th centuries BCE on, see Hayim Tadmor, "The Aramaization of Assyria: Aspects of Western Impact", in Mesopotamien und seine Nachbarn: politische und kuturelle Wechselbeziehungen im alten Vorderasien vom 4. bis 1. Jahrtausend v. Chr., Berliner Beiträge zum Vorderen Orient 1, 2nd Ed., eds. Hans-Jörg Nissen \& Johannes Renger (Berlin: Reimer, 1982), 449-70; Klaus Beyer, Die aramäischen Texte vom Toten Meer samt den Inschriften aus Palästina, dem Testament Levis aus der Kairoer Genisa, der Fastenrolle und den alten talmudischen Zitaten (Göttingen: Vandenhoeck \& Ruprecht, 1984), 28; Klaus Beyer, Die aramäischen Texte vom Toten Meer samt den Inschriften aus Palästina, 
The new situation enhanced the prestige and usefulness of Aramaic. Even if Aramaic became the lingua franca of the Neo-Assyrian, and of the Neo-Babylonian as well as of the Persian Empire (now as Achaemenid Official Aramaic), a lot of other languages and scripts continued to be used in the Ancient Near East (including the Southern Levant) and some newcomers were accepted as well.

The mechanisms of the language contact between Aramaic + language $\mathrm{X}$ are complex: in some cases, this contact entailed language maintenance (of the first language), where the language in contact continued to be spoken/written (as presumably in Assyria), but in other cases a language shift, because the majority of the speakers/ writers of the first language shifted to Aramaic (as presumably in Yehud). The script contact had even more options: for ancient writers, languages and scripts were not necessarily connected, so nearly any script could be used to write nearly any language. ${ }^{7}$ Attested is for example Aramaic language in Demotic script (papAmh 63), Phoenician language in Aramaic script (Arslan Taş), ${ }^{8}$ or Aramaic language in Akkadian syllabic cuneiform script. ${ }^{9}$

Thus, the use of the Aramaic language and script was extremely widespread and not limited to a single culture, identity, ethnicity, or even political entity. The use of Aramaic script was not even necessarily limited to the Aramaic language. In sum, Aramaic challenges any ideas about an essentialist link between language, script, identity, and ethnicity. It provides good arguments for not drawing sharp boundaries between languages.

In spite, or perhaps because of this complex sociolinguistic situation, the sociolinguistic rules and strategies for language choice in the different text types of the epigraphical and literary corpus of the multilingual Ancient Near East is a topic whose study has just recently begun. Since we must assume that the selection and combination of languages within a text group or within a text is not arbitrary or random within a multilingual

dem Testament Levis aus der Kairoer Genisa, der Fastenrolle und den alten talmudischen Zitaten 2 (Göttingen: Vandenhoeck \& Ruprecht, 2004), 16; Holger Gzella, A Cultural History of Aramaic, 53-156; Frederick M. Fales, "Multilingualism on Multiple Media in the Neo-Assyrian Period: A Review of the Evidence", State Archives of Assyria Bulletin, 16 (2007): 95-122.

7 For the complicated relationship between script and multilingualism in the Ancient Near East, see Gebhard J. Selz, "Scriptura Franca? Zur Rolle einer ideographisch basierten Schrift in einer mehrsprachigen Gesellschaft", in Mehrsprachigkeit. Vom Alten Orient bis zum Esperanto, dubsar 2, eds. Sebastian C. Fink, Martin Lang \& Manfred Schretter (Münster: Zaphon, 2018), 113-29.

8 Cf. e.g., Angelika Berlejung, "There is Nothing Better than More! Texts and Images on Amulet 1 from Arslan Tash", Journal of Northwest Semitic Language, 36/1 (2010): 1-42.

9 See Mark J. Geller, "The Aramaic Incantation in Cuneiform Script (AO $6489=$ TCL 6,58)", Jaarbericht Ex Oriente Lux, 35-36 (2000): 127-146, with BM 25636, the first renditions of an alphabet into late Babylonian cuneiform script. 
social setting, there should have been rules of text production. The research on these rules and the methodology for investigating multilingualism in ancient societies is still underexplored in historical sciences.

Therefore this study tries to offer some methodological considerations for the analysis of multilingualism in ancient sources. ${ }^{10}$ Based on a constructivist perspective, we claim that there is no essentialist link between language, script, identity, and ethnicity. ${ }^{11}$ However, scholars are convinced that there is a close and complex link between the different languages/linguistic means/linguistic practices and diverse identity options, performances and negotiations ${ }^{12}$ and that they play a key role in the strategies for language choice in the different text types and for the rules of text production in the multilingual Ancient Near East. In addition, this study discusses two examples of ancient texts that explicitly reject the choice of Aramaic in a multilinguistic context: a letter of Sargon II who rejects the use of Aramaic, and 2 Kings 18 where the Assyrian Rab-shaqeh is said to prefer Judahite/Hebrew to Aramaic. Both texts are considered as mirroring some central aspects of the intentional strategy of language choice and text production in the multilingual Ancient Near East.

\subsection{METHODOLOGICAL CONSIDERATIONS}

\subsubsection{Identity Options and Identity Performances in Ancient Languages and Scripts}

Identities depend always on what a person or a group is doing at a specific point in time and in place, and with specific social actors. Therefore, it is appropriate to quit the elusive concept of identity and to focus on "identity performances" instead. This means that the analyst's aim is to investigate the manner in which different identity

For a longer discussion cf. Angelika Berlejung, "Identity Performances in Multilinguistic Contexts: The Cases of Yarih-'ezer from Amman and Ikausu/Achish from Ekron", Welt des Orients, 49 (2019): 252-87.

11 Regarding the terms "ethnic identity", "ethnic group" and "ethnicity", I adhere to the definitions of Siân Jones, The Archaeology of Ethnicity: Constructing Identities in the Past and Present (London/New York: Routledge, 1997/Taylor \& Francis e-library, 2003), xiii; regarding the terms "personal/social/individual and collective identity", I rely on the definitions of Anna De Fina, "Linguistic Practices and Transnational Identities", in The Routledge Handbook of Language and Identity, ed. Siân Preece (London/New York: Routledge, 2016), 163-78.

Aneta Pavlenko \& Adrian Blackledge, "Introduction: New Theoretical Approaches to the Study of Negotiation of Identities in Multilingual Contexts", in Negotiation of Identities in Multilingual Contexts, Bilingual Education and Bilingualism 45, eds. Aneta Pavlenko \& Adrian Blackledge (Clevedon: Multilingual Matters, 2004), 1-33; Dorien van de Mieroop, "Identity and Membership", in The Routledge Handbook of Pragmatics (London/New York: Routledge, 2017). Published online, accessed 27 September 2018, 184-96. 
options are constructed, negotiated, and performed in their local, interactional - and with regard to our topic - multilinguistic context.

The essentialised view of identity and ethnicity that approach languages as separate entities that are used to mark particular ethnic and cultural identities fail especially in multilingual societies. ${ }^{13}$ Simple binary explanatory patterns conflict with the complexity of the historical and linguistic conditions and possible dynamics in the ancient Near Eastern societies. It is fundamentally problematic to regard distribution patterns of scripts and languages as an expression of ethnicity, or ethnic identity. The choice of a special language/script in a multilinguistic environment can be seen as a means to construct and to perform special identity options (included ethnic identity constructs), however the links between identity, ethnicity and language are neither primordial ${ }^{14}$ nor always decisive. The language/script choice and distribution pattern can also be explained by socio-economic or traffic- geographical prerequisites, if not even chronological variances or different social fields and objectives that were involved in-and determined the writers' choice of a script or a language and his text production.

For methodological reasons, it is advisable to understand distribution patterns of scripts and languages in written sources as regional phenomena and to ask about their settings in time, place, social actors, and possible identity productions, negotiations, and performances in their interactional context.

For methodological reasons we therefore argue in favour of:

- a movement away from static and essentialist models of identity, ethnicity and language and script towards process-oriented models of identity performance and communicative practice;

- an emphasis on linguistic repertoires rather than languages as fixed and bounded codes; and

The language-ethnicity link has been debated and contested, see, e.g., Peter Weinreich, "Variations in Ethnic Identity. Identity Structure Analysis", in New Identities in Europe. Immigrant Ancestry and the Ethnic Identity of Youth, ed. Karmela Liebkind (Hampshire: Gower, 1989), 41-76 esp. 58; Karmela Liebkind, "Ethnic Identity - Challenging the Boundaries of Social Psychology", in Social Psychology of Identity and the Self Concept, ed. Glynis M. Breakwell (London: Surrey University Press, 1992), 147-85; John Edwards, "Language in Group and Individual Identity", in Social Psychology of Identity and the Self Concept, ed. Glynis M. Breakwell (London: Surrey University Press, 1992), 129-146; John Edwards, Language and Identity: An Introduction (Cambridge: Cambridge University Press, 2009).

14 For an actual research overview of essentialist/primordialist and constructivist views on the link of language and ethnic identity compare Vally Lytra, "Language and Ethnic Identity", in The Routledge Handbook of Language and Identity, ed. Siân Preece (London/New York: Routledge, 2016), 131-45; Joshua A. Fishman, "The Primordialist-Constructivist Debate Today. The Language-Ethnicity Link in Academic and in Every-Day Life Perspective", in Ethnonationalism in the Contemporary World: Walker Connor and the Study of Nationalism, ed. Daniele Conversi (London/New York: Routledge, 2004), 83-91. 
- a focus on the role those repertoires play between interlocutors (or between readers and texts) in the personal or public sphere.

Finally, it has to be mentioned that there are sometimes good reasons for assigning individual script/language groups to a particular geographic area and providing them with a corresponding 'label' to indicate that they belong to a specific 'home country' and its inhabitants. This seems to be possible if 'definitely new immigrated innovations' are to be noted such as the emergence of traces of the Indo-European language family in the Semitic-speaking world.

\subsubsection{Multilingual Identities and Intercultural Pragmatics}

It is widely accepted that migration, colonialism, mobility and long distance trade are a motor for all kinds of multilingualism, and that multilingualism intersects with intercultural pragmatics, communication and contact linguistics. ${ }^{15}$ If we have a look on multilingual identities we have to assume that they are, just as identities in general, dynamic and subject to negotiation and performance in discourse. ${ }^{16}$ However, the communication of multilingual individuals is distinctive compared to monolingual individuals, because they can unintentionally transfer features from one language into another (called "interference") ${ }^{17}$ or they can intentionally use code mixing (switch from language to language on the word level), code switching (switch from language to language on word and sentence level), ${ }^{18}$ and translanguaging. The latter involves issues of language production, effective communication, the function of language, social and cognitive activities, the representation of values, identities and relationships, and the thought processes behind language use. ${ }^{19}$ In addition, emotional processes behind language choice should also be taken into consideration. ${ }^{20}$

Language choice, maintenance/shift, code mixing, code-switching and translanguaging are not only dependent on the availability of linguistic resources that the multilingual individual has at their disposal, but also on the symbolic value of speaking the

Els Oksaar, "The History of Contact Linguistics as a Discipline", in Kontaktlinguistik/Contact linguistics: Ein internationales Handbuch zeitgenössischer Forschung vol. I, Handbücher zur Sprach- und Kommunikationswissenschaft 12, eds. Hans Goebl, Peter H. Nelde, Zdene`k Stary, Wolfgang Wölck (Berlin: De Gruyter, 1996), 1-12.

Cf. Van de Mieroop, "Identity and Membership"; Cenoz "Bilingualism and Multilingualism", 144.

17 Alex Mullen, "Introduction: Multiple Languages, Multiple Identities", in Multilingualism in the Graeco-Roman Worlds, eds. Alex Mullen \& Patrick James (Cambidge: Cambridge University Press, 2012), 1-35 esp. 19.

18 For subdivisions in code switching see Mullen, "Introduction", 18.

19 See Cenoz "Bilingualism and Multilingualism", 144.

20 See the contribution of Barth in this volume. 
chosen language in the multilingual context. The self-attributed identity construct and performance, the communication situation, the context, the interlocutor, the motivation, the emotions, and the objectives can be factors that determine the language choice or shift of a multilingual individual. The choice of the languages which are selected and their status/prestige can be very significant and perform the speaker's/writer's affiliation to a special group and a social role: if a multilingual individual combined (or alternated) several high status languages, he performed with his strategy of language choice his cosmopolitan identity, and/or his membership to a transcultural international network, ${ }^{21}$ When a multilingual individual combined a high status language with a local dialect of lower prestige, or shifted "down" to a low status language, this strategy of language choice could be indebted to his ambitions to bridge social gaps or to perform his addiction to local traditions. Each case has its own logics and dynamics and should be studied thoroughly.

Code mixing, code-switching and translanguaging are categories that belong to individual multilingualism. They were observed and developed with living speakers in mind. In historical research we do not have speakers but scribes, and no oral but only written sources. It is often difficult to decide whether or to what extent a scribe made language choices and shifts in his work unintentionally, intentionally or on the basis of social conventions. A lot of different scenarios for text production are possible: a scribe could be obliged to use templates which were created by others or based on social convention, or he was expected to submit drafts which were corrected by his client(s) according to his/their wishes. Longer writings can also be the subject of long and complex editing and redactional processes. Many of the written sources are commissioned works, in which several people were involved under certain circumstances.

\subsubsection{What can we find out about Multilingualism and the Strategy of Language Choice in the Written Sources from the Past?}

Any portrait of the sociolinguistic situation of the Ancient Near East needs a multilevel and multi-dimensional sociolinguistic framework: At the macro level, we need to sketch the sociolinguistic landscape of the area, from the historical and geographical standpoints using theories of societal multilingualism (language contact, maintenance, shift, decline, death, dialect geography, language boundary, isoglosses). At the micro level, the sociolinguistic environment of selected individuals and their contemporaries has to be profiled, employing social and individual multilingualism theories (social language domains, diglossia, code mixing and switching, translanguaging, social 
network theory, always including concepts of identity constructions) in order to determine the function of the used languages (and their social status) and to understand the strategies of the language choice. On this level we assume ${ }^{22}$ that individuals are agentive beings who constantly seek and use social and linguistic resources which allow them to produce, negotiate, and perform their identities in discourse, and assign alternative meanings to the connections between identities and linguistic varieties. Hence, the local social meaning of the use of a linguistic repertoire and code in its particular context should be analysed. This use may index in-group or any other identity option, but it may just as well have many other functions.

Within the social multilingualism of the ancient Empires, languages shared different functions in different spheres of society or in regional distribution patterns. A question that is completely underexplored until today is whether and how far the ancient empires of the Ancient Near East supported multilingualism and, if so, by what means (e.g., education, bilingual coinage etc.). Another question can even be what impact social multilingualism could have on the language policy of the state and its legislation.

For any (re)construction of multilingualism and identity negotiations at the textual level, historical research is dependent on the selection of the material remains that have been found. Because the lower social classes were to a large extent illiterate and did not hold or produce any texts, we are mainly dealing with elitarians. Texts and scripts on perishable materials usually disappear over time, and so the writings on non-perishable materials dominate and determine our view and interpretation of the linguistic situation in past societies. Thus, historians who work with ancient written sources have to be aware of the fact that their materials are selective, accidental and fragmentary leftovers of ancient languages and scripts, sometimes therefore called limited or even "bad data". 23

In addition, trying to identify the author(s) of a text is not as easy a task as might be thought: it is often too difficult to associate any linguistic feature with a particular person/author or group. To begin with, multiple steps were required in the production of epigraphic texts on walls, rocks, stone, clay, fayence or metal, and each step (order, payment, drafting, producing, commissioning) might have been completed by different (one or more) individuals. Multilingual reference in a text could, therefore, be the product of more than one individual, who may, or may not, be named in the inscription. ${ }^{24}$ On the other hand there are some advantages in the study of multilingual

Following Pavlenko \& Blackledge, "Introduction", 27.

Katherine McDonald, “Fragmentary Ancient Languages as 'Bad Data': Towards a Methodology for Investigating Multilingualism in Epigraphic Sources", Sociolinguistica: Internationales Jahrbuch für Soziolinguistik, 31 (2017): 31-48.

With McDonald, "Fragmentary Ancient Languages", 32; Mullen, “Introduction”, 11-15. 
phenomena through written evidence. The human and material resources needed to produce a text (as opposed to a spontaneous utterance) may allow the analyst to be more certain regarding the text's intentions.

Written sources that show linguistic diversity and multilingual repertoires have to be analysed using the aforesaid levels of analysis as background information and communication theory, to identify the types of communication and interaction situations and possible strategies for the language choice and text production.

Backed by the observation that the evidence shows that in the epigraphical corpus some text types are more likely than others to contain references to multilingualism, Katherine McDonald recently proposed a new model for investigating multilingualism in the fragmentary corpora of written sources of dead languages (epigraphic sources) which includes the consideration of (1) the text type/text genre (within a corpus of similar texts if available), (2) its setting/domain (immediate social context), and (3) its layout/materiality/object type and its archaeological context. ${ }^{25}$

Backed by these preliminary methodological reflections, the answering of the following key questions seems to be seminal for future studies on multilingualism and the strategy of language choice in ancient written sources:

1. Can clear traces of linguistic diversity, language contact phenomena, and multilingualism be identified?

2. What can be said about the text's materiality, layout, spatial and archaeological context? What relevance have the location of the text, the text type and the text genre?

3. Which linguistic repertoire is used in the text, and what is the local social meaning of the use of a linguistic code in its particular context? Which affiliations and which differences to which social groups are constructed and performed?

4. Which types of communication and interaction situations and which strategies for the language choice can be identified in the text? What can be said about the author, his social context and his intentions?

5. How are script/language choice, maintenance, shift, code mixing, code switching or translanguaging (discursive multilingual practices) used in order to produce, index, negotiate and perform which identity constructs in their interactional context with (possible) monolingual and multilingual interlocutors/readers?

6. How are the used script/language choice, maintenance, shift, code mixing, code switching or translanguaging (discursive multilingual practices) dependent on 
the symbolic value of the chosen language in the multilingual context and on the intentions that the writer had?

7. Are there any hints in the text that point to official support of social multilingualism or to a clear language policy of the state and its legislation?

\subsection{ARAMAIC OR NO ARAMAIC? THE STRATEGY OF LANGUAGE CHOICE AND TEXT PRODUCTION IN MULTILINGUISTIC CONTEXT: TWO EXAMPLES}

\subsubsection{Sargon II (722-705 BCE)}

The ancient Near Eastern written sources mirror the aforesaid macro- and microlevels, dependent on the social context, text intention, text type and materiality/archaeological context. This high context-affinity also influenced the strategy of language choice and text production as well as the status of a language in the multilinguistic context of an Empire. This can be observed in the well-known royal letter of King Sargon II to Sin-iddin of Ur, CT 54, 10 (K 1159+): ${ }^{26}$

13. [As to what you (Sin-iddin) wrote:] "There are informers 14. [to the king ...] coming to his presence: 15.-17. If it is acceptable [to the k]ing, [let me] write down and send (my messages) to the king in Aram[aic] on scrolls (sipru)";

(Sargon's answer:) “17.-22. Why would you not write and send messages in Akkadian? Really, the message which you write must be drawn up like this - this is a fixed regulation $(i t t u)$ !..."

Within the Neo-Assyrian empire and on the macro-level as well as on the micro-level, the sociolinguistic environment of King Sargon II and his official Sin-iddin of Ur, the Akkadian and the Aramaic language, cuneiform as well as alphabetic script were both well-known and standard. ${ }^{27}$ The materiality of the writing medium clay for Akkadian and parchment/papyrus for Aramaic was considered a fact by the King and his official as well. Sin-iddin wanted to switch from Akkadian in cuneiform on clay to Aramaic in alphabet script on scrolls. He did not explain why, or Sargon did not quote his

Simo Parpola, The Correspondence of Sargon II, part 1. Letters from Assyria and the West, State Archives of Assyria 1 (Helsinki: Helsinki University Press, 1987), XVI; Manfried Dietrich, The Babylonian Correspondence of Sargon and Sennacherib, State Archives of Assyria 17 (Helsinki: Helsinki University Press, 2003), XV and no. 2.

For Aramaic loanwords in letters to Sargon II, see Giovanni B. Lanfranchi \& Simo Parpola, The Correspondence of Sargon II. Part 2, State Archives of Assyria 5 (Helsinki: Helsinki University Press, 1990), no. 64 rev. 4.6 and 156 rev. 6. See also Karen Radner, "An Imperial Communication Network: The State Correspondence of the Neo-Assyrian Empire", in State Correspondence in the Ancient World. From New Kingdom Egypt to the Roman Empire, ed. Karen Radner (Oxford: Oxford University Press, 2014), 64-93, esp. 80-84, and her contribution in this volume. 
explanation in his quotation because he did not care. As we can read, the king rejected Sin-iddin's innovation.

The scholarly discussion about Sargon II's letter tries to explain the royal veto as the result of "pride", that the King had reservations about "safety", ${ }^{28}$ stability and preservation, that he was ruled by identity matters, archival aspects, personal preferences, traditionalism, or whatsoever. It is also rash to deduce from Sargon's royal order that he was a monolingual person and identity. In his letter, Sargon II gives no reasons for his veto. He was the King, there was no need to give any argument. What we read in this letter does not mean, that Sargon II's royal veto was a general prohibition against the use of Aramaic in Assyria or in Assyrian administration or in royal business. His royal veto was connected and limited to the text type in discussion: royal correspondence to Assyria should always be written in Akkadian in cuneiform writing on clay tablets! In other contexts, and regarding other text types, he acted differently. Sargon II was not in general a conservative traditionalist in language and script matters; in other contexts he was even supporting multilingualism, and developed an integrative language policy.

We know from reliefs of Sargon II that he himself employed scribes who wrote the royal booty and prisoners' lists of his successful campaigns with ink on leather or papyrus, parallel to scribes who wrote in cuneiform on clay. ${ }^{29}$ Similar representations are known from later periods. ${ }^{30}$ Both writers on the reliefs seem to work synchronously. Sargon II's royal administration and booty management was bilingual while royal correspondence -especially between Assyria and Babylonia- was supposed to be not. His language choice of Akkadian on clay instead of Aramaic on scrolls in his letter to Sin-iddin of Ur is clearly indebted and limited to the given context (letters between Babylonia and Assyria) and to the text type 'royal letter'.

In war and diplomacy Sargon II was not against the use of Aramaic documents: on another relief of Sargon II. ${ }^{31}$ Assyrian soldiers offer a capitulation document to the enemy; it is a scroll, thus it has to be papyrus or leather and was surely inscribed in Aramaic script. The Assyrian attack depicted on this relief was against Pazaši, a border fortress between Mannaya and Zikirtu. Neither for the Assyrians nor for the enemy

28 Parpola, SAA 1, XVI.

29 Paul E. Botta \& Eugène Flandin, Monument de Ninive, vol. 1/2 (Osnabrück: Biblio Verlag, 1972 [Reprint of 1846-1850]), 2 pl. 146 = Parpola, SAA 1, fig. 6.

30 See, e.g., BM 124955 = Parpola, SAA 1, fig. 28 (ca. 630 BCE).

31 Botta \& Flandin, Monument de Ninive, 2 pl. 145 = Lanfranchi \& Parpola, SAA 5, fig. 9. On the interpretation, see Hayim Tadmor, "On the Use of Aramaic in the Assyrian Empire: Three Observations on a Relief of Sargon II", Eretz-Israel: Archaeological, Historical and Geographical Studies 20 (Yigael Yadin Memorial Volume) (1989): 249-52. 
of the East in Pazaši was Aramaic the first language. However, the Assyrians expected the élites of Pazaši to be able to read Aramaic. Therefore, they got the capitulation document in this language and script - and not in Assyrian on clay. The capitulary document presented was probably the Aramaic translation of an Assyrian model. The regulations of the capitulation document had to be understood and signed "directly at the gates" in order to keep peace between the contract partners. ${ }^{32}$

Thus, if we want to trace Sargon II's language policy referring to Aramaic, it becomes obvious that this was context bound and dependent on the text type. With the employment of alphabet scribes along with cuneiform scribes for administrative issues, lists and booty management, Sargon even supported the multilinguality of his administration. In the communication with his enemies and future subjugates, Aramaic was as the language of diplomacy and rulership. Within these contexts of Assyrian domination, Aramaic was in Sargon II's eyes the language of the underlings and of the periphery, not of the rulers and the Assyrian mainland. For the Assyrian King Aramaic had a lower status than Akkadian, and was not appropriate for royal correspondence. His language policy was therefore clearly context bound. Multilingualism and the strategy of language choice was part of political calculation, and of pragmatism. The social status of Aramaic in the Assyrian empire was dependent on the user, text type, text intention and context. This was true for Sargon and his subjugates. It made a difference who dictated the language choice: For the élites of Pazaši who were confronted with the Aramaic capitulation document, Aramaic was the language of the Assyrian empire and of their surrender. The meaning they assigned to the status of the Aramaic language was surely different to Sargon II's view about that. In the perspective of the oppressed people the use and the confrontation with Aramaic had an imperial connotation. It was in their eyes the language of the rulers and of Assyrian overlordship.

However, perhaps Sargon II's veto against Aramaic in his answer to Sin-iddin of Ur is not only indebted and limited to the text type 'royal letter', but also to the place of origin of the writer, Ur in Babylonia. It cannot be ruled out that letters to the Assyrian King from the western provinces and vassal states were treated differently: written documents in Aramaic from Aramaic speaking vassal states and provinces abroad were sometimes sent to the Assyrian King. Already Tiglath-pilesar III received Aramaic written documents in his capital. This is attested by a cuneiform letter found in Nimrud, which, although not dated, can be attributed to the reign of Tiglath-pilesar III 
(744-727 BCE), even more precisely after 730 BCE. ${ }^{33}$ In the letter in question, the governor of Șimirra, Qurdi-Aššur-lamur, writes to Tiglath-pilesar III and cites a report written in Aramaic received from Nabu-šezib who was probably an Assyrian official qepu stationed in Tyre. Qurdi-Aššur-lamur gives a summary in Akkadian of the Aramaic document that he had received: According to the report the King Hiram cut the sacred tree on the acropolis of Sidon and planned to transport it to Tyre. The Assyrian official stopped him, and - even if Nabu-šezib's report is badly broken in rev. 13 - he seems to describe the death of King Hiram. Qurdi-Aššur-lamur cites the report of Nabu-šezib which came to him as a sealed Aramaic document: ${ }^{34}$

1f. [To the k]ing, my lord, your ser[va]nt, Qurdi-Aššur-lamur:

3. This sealed Aramaic document (ka-ni-ku an-ni-tú KUR.ár-mi-tú) 4. Nabušezib from Tyre 5. sen[t to me]. Following: "To the palace

6. [let] it be sent." To the palace 7. I have sent it.

(Further information on the sacrilege of King Hiram (739-730 BCE) cutting down the sacred tree on the acropolis in Sidon and his death follow.)

The sealed Aramaic letter is lost, but the accompanying Assyrian tablet preserved here as ND 2686 used it as its source and based on it, Qurdi-Aššur-lamur informs Tiglath-pilesar III about activities in Sidon and Tyre. This indicates the practice that the qepu Nabu-šezib had sent some kind of spy report in Aramaic to his authority, the governor. The governor's office collected informations and reports like this, and forwarded important Aramaic documents to Assyria, together with an accompanying comment or abstract to the King which was written in the traditional form of a royal letter in Akkadian and cuneiform writing. The royal letter written in Akkadian summarised the key issues and authentified the source of information. In this case, Qurdi-Aššur-lamur had the sealed Aramaic document of Nabu-šezib and forwarded the information to Assyria.

The governor's office had to be bilingual, to be able to read Aramaic reports, to select and evaluate them, and to provide translations and summaries in Akkadian language and cuneiform script. The sealed Aramaic report from Tyre had been sent to the governor and via him to Assyria, accompanied by the Akkadian royal letter. The

33 For the historical discussion, see Shigeo Yamada, "Qurdi-Assur-lamur: His Letters and Career", in Treasures on Camel's Humps. Historical and Literary Studies from the Ancient Near East Presented to Israel Eph'al, eds. Mordechai Cogan \& Dan'el Kahn (Jerusalem: Hebrew University Press, 2008), 296-311, esp. 299-301; Nadav Na'aman, "Qurdi-Aššur-lamur as Governor in Phoenicia and South Syria", Notes Assyriologiques Brèves et Utilitaires 1 (2018): no. 26.

34 Mikko Luukko, The Correspondence of Tiglath-Pileser III and Sargon II from Calah/Nimrud, State Archives of Assyria 19 (Helsinki: Helsinki University Press, 2012), no. 23 (= ND 2686 = CTN 5, 154f t30b). 
Aramaic document was the Vorlage for the summary of the events in Tyre which was signed by the governor. The Aramaic Vorlage which was summarised in the Akkadian letter had changed the text genre (from spy report to a royal letter), the language, script and materiality (from Aramaic on papyrus/leather to Akkadian on clay). The report of Nabu-šezib became part of a royal letter that provided the king of Assyria with background information. It had been double-checked before. The interaction of the different officials in Assyrian service shows clearly that the choice of the language in the multilinguistic context of the Assyrian Empire was already since Tiglath-Pileser III and Sargon II connected to context, text intention, text type, to pragmatism as well as to political matters.

\subsubsection{Kings 18:26-29 (//Isa 36:11-14//2 Chr 32)}

The motivations and objectives behind the strategy of language choice in multilinguistic contexts is even reflected in the Bible: 2 Kings 18:26-29 par. describes the language contact and encounter between multilinguistic individuals in the fiction of a hypothetical event. ${ }^{35}$ The following verses belong to the opening of a longer speech of the Assyrian Rab-shaqeh of the Assyrian King Sennacherib (705-681 BCE) challenging the élites and people of Jerusalem, their King and their god:

26. Then Eliakim, the son of Hilkiah, and Shebna and Joah said to the Rabshaqeh: "talk to your servants in the Aramaic language! For $(k y)$ we understand, and do not speak Judahite with us, in the ears of the people which is on the wall."

27. But the Rab-shaqeh said to them: "Is it to your master or to you that my master has sent me to say these words? Has he not sent me to the men seated on the wall eating their dung and drinking their urine (as long as they are) with you?"

28. Then the Rab-shaqeh stood and called with a loud voice in Judahite, and he spoke and said: "Hear (pl.) to the words of the great king, the king of Assyria!

29. This is what the king says: 'Hezekiah may not trick you, for he is not able to rescue you from his [my] hand'".

Disregarding the historicity and theological core of this narrative, the writer of this story refers to linguistic practices to indicate an in- and an out-group. He points out

Any ideas about the Rab-shaqeh's Israelite identity, ethnicity, knowledge of Hebrew and YHWH theology are futile (for an in-depth discussion of these ideas, see Cian J. Power, Many Peoples of Obscure Speech and Difficult Language: Attitudes towards Linguistic Diversity in the Hebrew Bible [Doctoral Dissertation, Harvard University, Graduate School of Arts \& Sciences, 2015], 250-60). Whether the Assyrian conquerors learned the languages of the invaded nations (so Daniel I. Block, "The Role of Language in Ancient Israelite Perceptions of National Identity", Journal of Biblical Literature, 103 [1984]: 321-40, esp. 328 n. 27) is also unclear. The authors/ editors of 2 Kings 18 par. are not interested in explaining the Rab-shaqeh's or the Judean élites' linguistic competences. 
(v. 26) that the wish of the bilingual Judean élite to switch from Judahite/Hebrew to Aramaic in the conversation with the Assyrian Rab-shaqeh, had the intention to exclude the local monolinguals (speaking only Judahite/Hebrew) from the diplomatic negotiations. They wanted to create a social gap and redefine the boundaries of the discourse. ${ }^{36}$ That these negotiations were nothing less than a capitulation is evident in the progress of the story and history.

In contrast, the multilingual Assyrian diplomat's switch from Aramaic to Judahite/ Hebrew (vv. 27-29), was motivated by the author by the idea that the Assyrian official wanted to talk to the citizens of the occupied city and to convince them to surrender. The Rab-shaqeh is described as a tactical person whose language choice was motivated by his ambitions to bridge social distance, and to communicate with a larger audience including all social classes of Jerusalem. The author/editor of the story clearly attributes multilingualism and Aramaic to the élites of the royal court (in Assyria and in Jerusalem), monolingualism and the local tongue to the lower social classes. In addition, he points out that the choice of Aramaic connects the Judean and Assyrian upper classes, even if they do not share the same ethnicity and religion. On the other hand, the choice of Aramaic is said to disconnect the lower Judean social groups from their upper-class compatriots, even if they do share the same ethnic and religious identity.

In contrast to Aramaic, the language choice of Judahite/Hebrew excludes nobody in the story: it connects the lower and the upper Judean social classes as well as the foreign Rab-shaqeh. His choice of Judahite/Hebrew creates an in-group which connects different social classes, different ethnicities and different religions. In the text it is said that it is the explicit wish of the Judean upper class, not to have that. They want to exclude their compatriots from the communication. The author/editor therefore refers to language as a means of social control, and discrimination. ${ }^{37}$ That language choice is also a means of manipulation becomes clear in the speech of the Rab-shaqeh. His language choice and switch to Judahite/Hebrew are marked as being indebted to pure political calculation. By using the (compared to Assyrian or Aramaic) low status language Judahite/Hebrew, the Assyrian diplomat communicates his King's message to all sections of the Judean population. The intention of his language downgrading is quite clear: he wants to bring all social classes on his side and calls for their revolt against King Hezekiah. The re-told story of this narrative in $2 \mathrm{Chr}$ 32:18 also points out that the choice of the language was intended to frighten and terrify the ordinary

36 See also Power, Many Peoples, 245-46.

37 Power, Many Peoples, 248 observes correctly, that the characters (Rab-shaqeh and Judean élite) were positioned by respectful (Judeans) vs. disrespectful (Rab-shaqeh) language and "play out the respective roles of their masters". 
people on the wall. The Chronicler concludes from his Vorlage in 2 Kings 18 that the words spoken in the Judahite/Hebrew language had the power to arouse emotions.

The author/editor of 2 Kings 18:26-29 plays with the advantages and disadvantages of multi- and monolingualism as well as with the status of languages in a sophisticated manner. At the end the reader is inclined to understand that multilingualism is an advantage, because it reduces for the multilingual individual the options of getting only selective information, being excluded and manipulated. On the other hand, the multilinguistic individual (as the Rab-shaqeh) has more possibilities to manipulate others.

The strategy of language choice of the multilinguistic individuals in the story (Judean élites and the Assyrian official) is marked as being indebted to their political objectives and motivations. And as a lesson, it can be understood by the reader that language is not always a marker of difference and that not everybody who talks to you in your own language, is on your side. Language can be used by tricksters, and it is good to be prepared. Within the context of this theological story-telling the confidence in YHWH, the God of Jerusalem, is the best way to handle any challenges.

It is also worth mentioning that Aramaic has in this Biblical account a high status. It is - seen from the Judean perspective - the language of the élite, diplomats, and of the rulers. The Aramaic speaking people decide the fate of the Judahite/Hebrew speaking people. This surely reflects the reality of the Neo-Assyrian empire. Upper class people spoke Aramaic and diplomacy relied on this language.

\subsection{CONCLUSION}

At the level of the written language, multilingualism is tangible in various aspects in ancient sources, while the processes at the level of the spoken language can no longer be verified. Historical research on ancient written sources can learn from actual research on multilingualism, that multilingual linguistic practices are highly discursive and context-sensitive, and that strategies of language choice, language shift or maintenance, intentional multilinguistic practices or unintentional interferences, are the rule in multilingual contexts and can be connected to terms of identity production, negotiation and performances. But the purpose and function of the language choice can also depend on the status/prestige of the languages that were at the writers' disposal, and of a whole set of political, religious, social, or economic factors of influence. In any case, for the historical analysis of multilingualism and the understanding of the strategy of language choice in the written sources from the Ancient Near East it is important to take the text type and text genre, its materiality, and its full textual, social, and archaeological context into consideration. 
In the multilingual macro-context of the Ancient Near East, the strategy of language choice was inseparable from political and social arrangements, relations of power or access to capitals, religions, language ideologies and status, and interlocutors'/writers' views of their own and of the others'/readers' identities. Any religious, ideological, and political changes affected these constellations, modifying identity options and the strategy of language and script choice on the microlevel and were thus highly discoursive and context-sensitive.

Regarding the use of and language policy with Aramaic, it could be shown that it was of significant importance who determined the choice of language. Who selected the language defined the framework of communication and the possible interlocutors as well as the further conditions. The two presented text examples (letter of Sargon II, and 2 Kings 18) belong to very different text types, text genres and do not share the same text intentions. However, both texts mirrored central aspects of the intentional strategy of language choice and text production in the multilingual Ancient Near East: Even if 2 Kings 18:26-29 designed a paradigmatic and fictional multilinguistic encounter, its author/editor referred to Aramaic as the prestigious language of the élites and to language choice as a means of social control, discrimination, and manipulation. The meaning that was assigned to the status of Aramaic by the Neo-Assyrian language policy of the state was dependent on the communication partners, text type, text intention and context, to pragmatism as well as to political matters; while for Sargon II Aramaic was the language of the periphery, administrative management, capitulation documents and of the underlings, for the conquered people Aramaic was the language of the Assyrian oppressor who dictated their fate. 